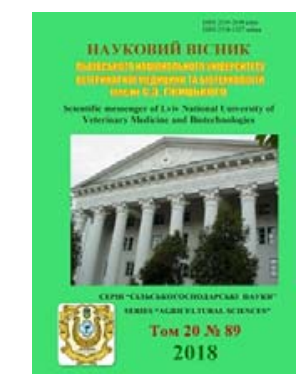

Науковий вісник Дьвівського національного університету ветеринарної медицини та біотехнологій імені С.3. Гжицького

\author{
Scientific Messenger of Lviv National University \\ of Veterinary Medicine and Biotechnologies
}

\title{
Efficiency of the transfer of cows for tieless maintenance and their feeding under intensive technology of milk production
}

\author{
I.V. Hnoievyi, R.U. Batyr, T.S. Voitenko \\ Kharkiv State Zooveterinary Academy, Kharkiv, Ukraine
}

\section{Article info}

Received 31.08.2018 Received in revised form 26.09.2018 Accepted 28.09.2018

Kharkov State Zooveterinary Academy, Akademichna Str., 1, Mala Danylivka, Kharkiv region, Dergachi district, 62341, Ukraine. Tel.: +38-097-470-72-45 E-mail:hgzva1810.1965@gmail.com

\begin{abstract}
Hnoievyi, I.V., Batyr, R.U., \& Voitenko, T.S. (2018). Efficiency of the transfer of cows for free pen maintenance and their feeding under intensive technology of milk production. Scientific Messenger of Lviv National University of Veterinary Medicine and Biotechnologies, 20(89), 22-26. doi: $10.32718 /$ nvlvet8904
\end{abstract}

The paper presents the results of research in the working conditions of an agricultural enterprise that studies the efficiency of double, triple and triple partly milking of cows in connection with their transfer from a fixed content to a tieless box and the addition of some green mass into the contents of the feed mix. The purpose of our research was to determine the efficiency of different ratios of green and conserved feeds in the ration of dairy cows during summer period; to study the effect of the frequency of milking on the milk productivity of the Black-and-White breed cows in the conditions of cows' transfer to the tieless maintenance at the intensive technology of milk production. The investigation was carried out in the conditions of the agro-firm № 10 of the state enterprise "Illich Agro-Donbas", Mariupol district, Donetsk region. The dairy cows of the Ukrainian Black-and-White breed were used in our experiment that was conducted in accordance with the generally accepted methods of the research on cattle feeding. Before the beginning of the research the cows were kept on a leash all-year-round. The experiment was carried out and during the experiment the technology of maintenance and milking of the cows in the control group remained unchanged, the cows-analogues of the second group were transferred to the new, reconstructed livestock house for the tieless maintenance, for the first hundred days of lactation the cows were milked three times a day and they were milked twice a day till the end of the lactation. The cows of the third group were under tieless conditions of maintenance and they were milked three times a day throughout the lactation period. The feeding conditions for the cows were the same, that is, the animals were fed with the balanced feed mixtures at the silage-concentrate type of feeding. The partial replacement of the brought up (mown) green feeds of the field forage production in the ration of dairy cows in stalls and under unleashed pen maintenance by high quality silage met the physiological requirement of the cows in dry matter and at the same time it increased the concentration of energy in $1 \mathrm{~kg}$ of the ration. The following results were obtained. When keeping the cows tied and tieless at the partial replacement of the brought up (mown) green feeds of the field forage production in the ration of lactating cows by the high quality silage better provides their physiological requirements in dry matter and at the same time it increases the energy concentration in $1 \mathrm{~kg}$ of the ration. The use of partly both three-time milking (for the first hundred days of lactation) and three-time milking (during the whole period of lactation) increased the milk productivity of the cows by 7.0 and $11.4 \%$, with the simultaneous decrease in the feed costs per a unit of produce by 7.2 and $11.8 \%$, respectively. The lactation activity of the cows that were milked twice a day was more fluent and uniform and the intensity of milk yield was significantly higher as compared with the cows of groups 2 and 3 by $29.4 \%$ and $26.5 \%$, respectively. The economic efficiency of milk production was higher in group 2 and 3 , the profit in the above groups exceeded the profit of group 1 by $4.7 \%$ and $5.4 \%$, respectively. bility.

Key words: cow, milking ratio, feed mix, green mass, lactation curve, milk yield, milk quality, profita-

\section{Ефективність переведення корів на безприв'язне боксове утримання та їх годівля за інтенсивної технології виробництва молока}

\author{
І.В. Гноєвий, Р.Ю. Батир, Т.С. Войтенко
}

Харківська державна зооветеринарна академія, м. Харків, Україна 
У роботі наведені результати досліджень у виробничих умовах сільськогосподарського підприємства щчодо ефективності двократного, частково трикратного та трикратного доїння корів у зв'язку з їх переведенням із прив'язного утримання на безприв'язне боксове та введенням зеленої маси до складу кормосуміші. Метою наших досліджень було визначення ефективності різного співвідношення зелених і консервованих кормів у раціонах дійних корів упродовж літнього періоду, вивчення впливу кратності доӥння на молочну продуктивність корів чорно-рябої породи в умовах переведення їх на безприв'язне боксове утримання за інтенсивної технологї виробництва молока. Робота проводилась в умовах агрочеху № 10 ДП “Ілліч Агро-Донбас”, Маріупільського району Донеиької області з використанням дійних корів української чорно-рябої породи відповідно до загальноприйнятих методів досліджень з питань годівлі великої рогатої худоби. До початку проведення досліджень дійні корови утримувались цілорічно на прив'язі. Був проведений експеримент, у ході якого технологія утримання і доӥння контрольної групи корів залишилась незмінною, друга група корів-аналогів була переведена у нове, реконструйоване тваринницьке приміщення на безприв'язно-боксове їх утримання, доїння периі сто днів лактації-триразове, до закінчення лактації-дворазове. Третя група корів-аналогів - безприв язнобоксове утримання, як і у корів другої групи, триразове доӥння протягом усієї лактації. Умови годівлі корів були однаковими, тобто тварини споживали збалансовані кормосуміші за силосно-концентратного типу годівлі. Були отримані такі результати. Часткова заміна підвізних (скошених) зелених кормів польового кормовиробництва високоякісним силосом у раціонах дійних корів за стійлового та безприв'язного боксового утримання краще забезпечує їх фізіологічну потребу в сухій речовині з одночасним підвищенням концентрації енергї в 1 кг раціону. Використання як частково трикратного (перші 100 днів лактації), так $і$ трикратного доїння (за весь період лактації) корів підвищує молочну продуктивність на 7,0 та 11,4\% з одночасним зниженням кормовитрат на одиниџю продукиї на 7,2 та 11,8\% відповідно. Лактаційна діяльність корів, яких доӥли два рази на добу, більи плавна і рівномірна, також інтенсивність молоковіддачі у них була вірогідно більшою, ніж у тварин другої групи на 29,4\% і третьоїна 26,5\%. Економічна ефективність виробництва молока була вищою у другій і третій групах, де прибуток перевищував периу групу на 4,7\% та 5,4\% відповідно.

Ключові слова: корова, кратність доӥння, кормосуміш, зелена маса, лактаційна крива, інтенсивність молоковіддачі, якість молока, рентабельність.

\section{Вступ}

У молочному скотарстві України широкого розповсюдження набула комбінована годівля високопродуктивних корів консервованими кормами (сіно, сінаж, силос) в літній період (Hnoievyi, 2003). Водночас за реконструкції тваринницьких ферм та переведення корів із прив'язного утримання на безприв'язне боксове 3 доїнням їх в доїльному залі виникає необхідність забезпечити високопродуктивних тварин поживними речовинами настільки, щоб максимально знизити їх стресочутливість, тим самим уникнути вимушеного спаду іх продуктивності (Admin and Korol', 2006; Valchuk et al., 2016; Dundun, 2016; Ordihovska and Litskyy, 2016).

У виробничих умовах не існує єдиного підходу щодо реалізації цієї проблеми. Цілорічно однотипна годівля корів кормосумішами у літній період за комбінованого використання консервованих і зелених кормів вже використовується у більшості кращих господарств України. Як свідчать наші дослідження, використання зелених кормів у складі таких кормосумішей краще забезпечує їх фізіологічну потребу в сухій речовині з одночасним підвищенням концентрації енергії в 1 кг раціону, дає можливість підтримувати нормальну вгодованість та відтворювальну здатність тварин, сприяє росту їхньої молочної продуктивності за перші 100 днів лактації, підвищенню його якості, зниженню загальних витрат кормів (Stepanov and Naumov, 2006; Kosior, 2009; Bomko et al., 2018). Дослідження щодо оптимального введення зелених кормів до складу кормосумішей за переведення високопродуктивних тварин на іншу технологію їх утримання залишались неповними (Hnoievyi et al., 2004).

До того ж промислова технологія виробництва молока потребує створення високопродуктивних стад тварин, які пристосовані до нового типу машинного доїння (Admin and Korol', 2006; Pidpala and Yaseniv, 2011).

Метою наших досліджень було визначення ефективності різного співвідношення зелених і консервованих кормів у раціонах дійних корів упродовж літнього періоду, вивчення впливу кратності доїння на молочну продуктивність корів чорно-рябої породи в умовах їх переведення на безприв'язне боксове утримання за інтенсивної технології виробництва молока.

Для досягнення поставленої мети були визначені такі завдання:

- вивчити ефективність співвідношення консервованих і зелених кормів у літній період у складі кормосуміші для корів за їх переведення зі стійлового прив'язного утримання на безприв'язне боксове;

- визначити ефективність дворазового, частково триразового і триразового (протягом всієї лактації) доїння високопродуктивних корів у зв'язку з їх переведенням із прив'язного утримання на безприв'язне боксове та за введення зеленої маси у склад кормосуміші;

- визначити економічну ефективність виробництва молока за частково трикратного і триразового доїння.

\section{Матеріал і методи досліджень}

Робота проводилась в умовах агроцеху № 10 ДП “Ілліч Агро-Донбас", Маріупільського району Донецької області 3 використанням дійних корів української чорно-рябої породи відповідно до загально прийнятих методів досліджень 3 питань годівлі великої рогатої худоби.

Дійних корів утримували цілорічно прив'язно, а годівля ї здійснювалася 3 кормових столів кормосумішками, що складалися 3 консервованих i зелених кормів, де на останні припадало 18-20 кг на голову (11,7\% в структурі раціону) за добу (рис. 1$)$.

Був проведений виробничий експеримент. Тваринницьку ферму реконструйовано з прив'язного на безприв'язне боксове утримання корів 3 доїнням їх в 
доїльному залі, який оснащено доїльною установкою "Карусель" фірми "Westfalia Surge" на 32 місця. Для проведення досліджень було відібрано 3 групи коріваналогів: I група корів залишилась на прив'язі, протягом 305 діб лактації корів доїли два рази: о 5-й ранку та о 17-й годині ввечері; II група: перші сто днів лактації корови були переведені на безприв'язне боксове утримання та доїлися три рази, наступні двісті п'ять днів - два рази на добу; III група - корови за безприв'язного боксового утримання протягом усієї лактації доїлися три рази: о 6-й ранку, о 12-й в обід та о 18-й годині ввечері. Корови всіх груп споживали кормосуміш за одним рецептом. Лактацію корів вивчали 3 травня 2016 року до березня 2017 року.

\section{Результати та їх обговорення}

Для годівлі тварин використовували силосноконцентратний тип, а корми згодовувались у вигляді повноцінної кормосуміші за допомогою кормороздавача-міксера Verti-Mix 500. За весь період лактації корови всіх груп спожили 4798 ц корм. од. Відповідно витрати кормів склали 0,93 корм. од.

Характерною особливістю такої кормосуміші було те, що частка силосу у структурі була 27,6\% (рис. 1), але зросла його якість у зв'язку зі заміною $55 \%$ кукурудзяного силосу на комбінований (кукурудза + соя) (рис. 2).

Враховуючи продуктивність корів, споживання ними комбікорму у складі кормосуміші було на високому рівні - 37,9\% (рис. 1).
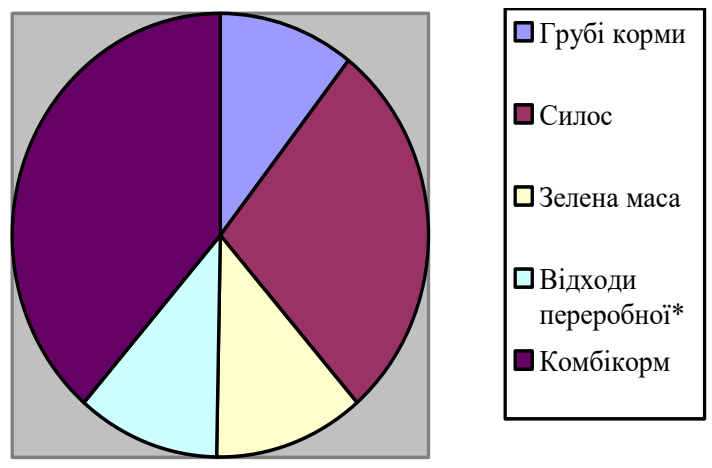

* Відходи переробної промисловості - дробина, жом

Рис. 1. Структура кормосуміші (\% за поживністю)

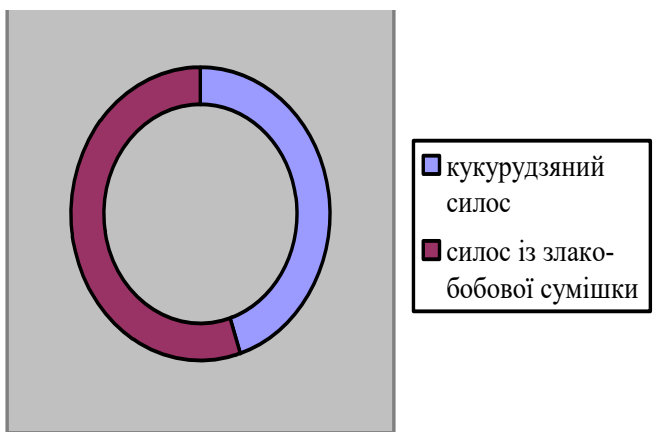

Рис. 2. Структура силосу

Аналізуючи дані, отримані при оцінці корів за молочною продуктивністю, можна відзначити, що най- нижчі показники серед ровесниць з надоїв за 100 днів лактації мали тварини першої контрольної групи, які були на прив'язному утриманні і їх доїли два рази на добу протягом всієї лактації. Надій корів цієї групи склав 1625,3 кг і був вірогідно нижчим, ніж у другій групі, на 124,5 кг (7,7\%) і ніж у третій - на 196,6 кг $(12,1 \%)(\mathrm{P}<0,05)$ відповідно. Тобто найвища продуктивність корів була досягнута у третій групі корів i склала 1821,9 кг на голову, але різниця щодо другої групи була не вірогідною і складала всього 72,1 кг, або на $4,1 \%$ більше $(\mathrm{P} \geq 0,05)$.

Найкращу молочну продуктивність за 305 днів лактації показали тварини третьої групи - на безприв'язному утриманні, яких доїли три рази за добу, їхній надій склав 5153,5 кг на одну голову. Вони перевищували цей показник ровесниць першої та другої груп на 587,8 (12,9\%, P < 0,05) і 244,3 кг $(5,0 \%, \mathrm{P} \geq$ $0,05)$ відповідно, тобто різниця між другою і третьою групами була невірогідною. Найменшу продуктивність виявили корови першої групи, яких доїли два рази за добу протягом всієї лактації. Їх надій за 305 днів лактації склав 4565,7 кг, що достовірно менше $(\mathrm{P}<0,05)$ порівняно 3 другою групою на 343,5 кг $(7,0 \%)$ і на 587,8 кг $(11,4 \%)$ менше проти третьої групи $(\mathrm{P}<0,05)$.

Молочна продуктивність корів за різної кратності доїння показана на рис. 3 і 4. Середньодобовий надій на корову також був найменшим у першій групі i склав 15,22 кг, що на 1,14 кг (7,5\%) менше, відносно другої групи $(\mathrm{P}<0,05)$ і на 1,96 кг $(12,9 \%)$ менше третьої групи $(\mathrm{P}<0,05)$.

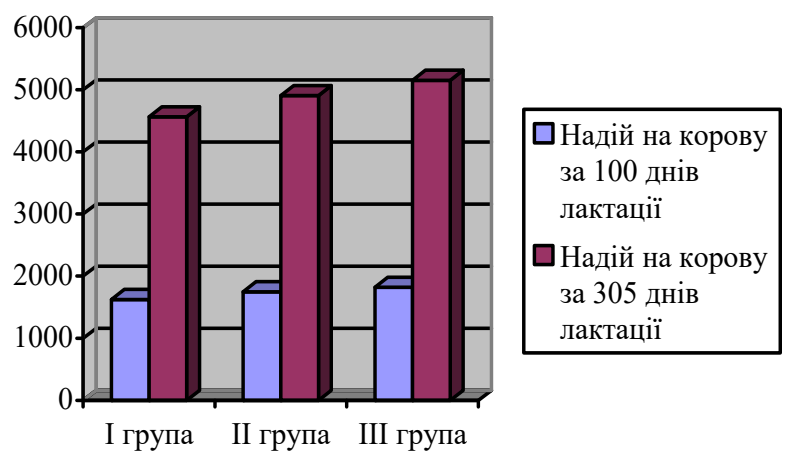

Рис. 3. Молочна продуктивність корів за різної кратності доїння

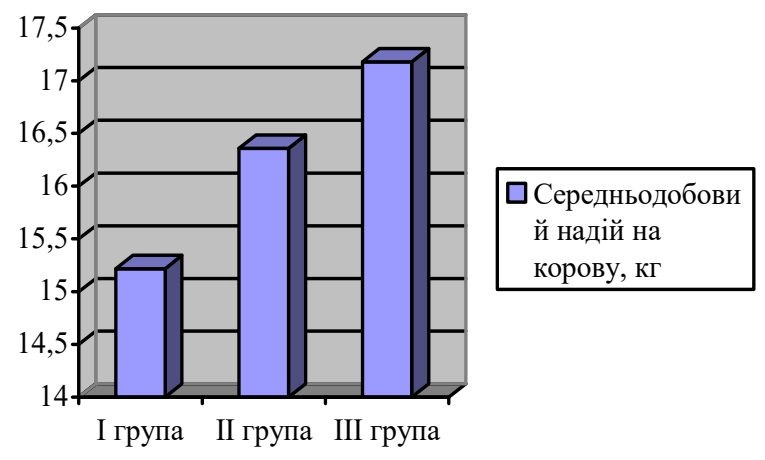

Рис. 4. Середньодобовий надій на корову 
Порівняльний аналіз середньодобових надоїв корів залежно від кратності доїння показав, що триразове доїння в перші сто днів лактації у другій групі дало вірогідне перевищення порівняно 3 тваринами першої групи: у перший місяць на 1,25 кг $(7,4 \%, \mathrm{P}<0,05)$, у другий місяць - на 1,30 кг $(6,9 \%, \mathrm{P}<0,05)$, у третій на 1,62 кг (8,8\%, Р < 0,05). У наступні місяці лактації, коли корів і першої і другої груп доїли два рази за добу, середньодобовий надій тварин другої групи не вірогідно перевищував аналогів першої групи: у четвертому - на 0,7 кг (3,9\%), у п’ятому - на 0,37 кг $(2,3 \%)$, у шостому - на 0,87 кг $(6,3 \%)$, у сьомому - на 0,87 кг $(6,1 \%)$, у восьмому - на 1,27 кг $(9,9 \%, \mathrm{P}<$ $0,05)$, у дев’ятому - на 1,66 кг $(14,2 \%, \mathrm{P}<0,05)$, у десятому - на 1,47 кг $(13,7 \%, \mathrm{P}<0,05)$.

Порівняння середньодобових надоїв корів третьої групи 3 першою виявило чітку закономірність перевищення їх у всі місяці лактації, за винятком четвертого і п'ятого місяців, коли, незважаючи на триразове доїння, тварини третьої групи більш стрімкими темпами зменшували свою продуктивність. Так, у перший місяць ця різниця складала 2,57 кг (15,2\%,

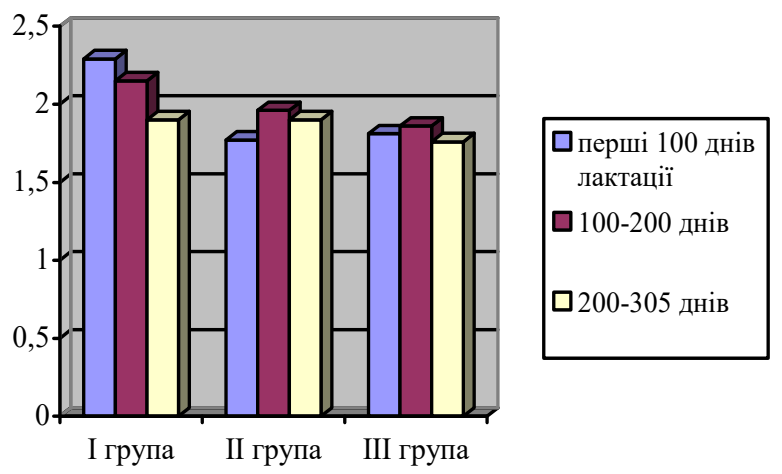

Рис. 5. Інтенсивність молоковіддачі корів за різної кратності доїння, кг/хв

Встановлено перевагу тварин першої дослідної групи (двократне доїння на прив'язі протягом всієї лактації) за інтенсивністю доїння над ровесницями 3 інших груп. Так, в цілому за добу у перші 100 днів лактації швидкість молоковіддачі була більшою, чим у тварин другої групи на 0,52 кг/хв $(29,4 \%$, Р < 0,05) i третьої на 0,48 кг/хв $(26,5 \%, \mathrm{P}<0,05)$, у другий період лактації (100-200 днів) - на 0,23 кг/хв (11,8\%, Р < $0,05)$ і 0,22 кг/хв $(11,2 \%, \mathrm{P}<0,05)$, у останні 100 днів лактації - на 0,14 кг/хв $(8,0 \%, P \geq 0,1)$, чим у третій, а 3 другою групою вона вирівнялась.

У результаті дисперсійного аналізу встановлена сила впливу (Rx) кратності доїння на тривалість доїння корів - 0,563 (56,3\%) $(\mathrm{P}<0,001)$.

Молочна продуктивність визначалася не тільки кількістю, а й якістю молока. Основними показниками якості молока $є$ утримання в ньому масової частки жиру і білка.

Найбільша масова частка жиру за перші 100 днів лактації відмічена в першій групі тварин - 3,79\%, що вище на $0,01 \%$, ніж у другій і третій групах.

Масова частка білка за аналогічний період в першій групі також була найбільшою - 3,09\%, що на
$\mathrm{P}<0,05)$, у другий місяць - на 1,73 кг $(9,1 \%, \mathrm{P}<0,05)$, у третій - на 2,26 кг $(12,3 \%, \mathrm{P}<0,05)$, у четвертому на 1,47 кг $(8,3 \%)$, у п'ятому - на 1,29 кг $(8,3 \%)$, у шостому - на 1,75 кг $(11,8 \%, \mathrm{P}<0,05)$, у сьомому - на 1,80 кг $(12,5 \%, \mathrm{P}<0,05)$, у восьмому - на 1,99 кг $(15,6 \%, \mathrm{P}<0,05)$, у дев'ятому - на 2,46 кг $(21,03 \%$, $\mathrm{P}<0,05)$, у десятому - на 2,28 кг $(21,03 \%, \mathrm{P}<0,05)$.

Аналіз валового виробництва продукції за 305 днів лактації також підтвердив перевагу тварин другої i третьої груп за величиною надою молока над аналогами першої контрольної групи (дворазове доїння 146102 кг за старого методу утримання) на 10992 кг (7,5\%) та 18811 кг (12,9\%) відповідно. Різниця між другою і третьою групами складала 7819 кг (5,0\%).

Швидкість віддачі молока - одна 3 основних характеристик придатності корови до машинного доїння за відсутності у тварини негативного впливу стресу. Середня швидкість доїння корів, на думку багатьох дослідників, перебуває в прямій залежності від величини разового удою. Найважливішим показником придатності корів до машинного доїння $є$ інтенсивність молоковіддачі (рис. 5 і 6).

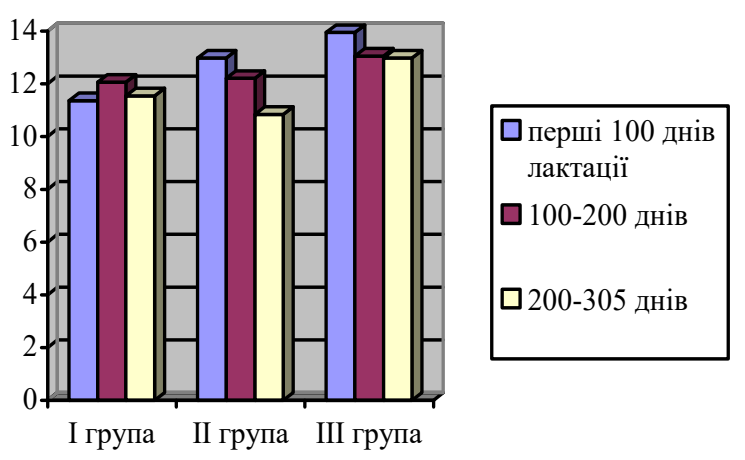

Рис. 6. Коефіцієнти варіації (Cv, \%) показників інтенсивності молоковіддачі корів

0,01\% перевищує дані другої і третьої груп. Але за рахунок вищої молочності валове виробництво молочного жиру і білка на одну голову худоби в першій групі було найменшим. Тобто, жиру вироблено у другій групі на 4,67 кг (7,6\%), у третій на 7,34 кг $(11,9 \%)$ більше відносно першої. Білка також відповідно більше було зафіксовано у другій групі на 3,67 кг (7,3\%) і у третій на 5,95 кг (11,9\%).

За 305 днів лактації була відмічена така сама закономірність якісних показників молока. Тобто масова частка білка і жиру кращою була у першій групі i перевищувала аналогів другої групи на 0,01\% і 0,01\%, третьої - на 0,03\% і 0,01\% відповідно. Проте, валове виробництво молочного жиру в першій групі було найменшим - 174,06 кг, що на 12,53 (7,2\%) і 20,85 кг (12,0\%) менше, ніж у другій і третій відповідно. Білка також при двохразовому доїнні отримано менше $(139,75$ кг) на 10,21 кг (7,3\%) i 17,39 кг (12,4\%), порівняно $з$ двома іншими.

Більш висока продуктивність корів за частково трикратного і триразового доїння забезпечила вищі економічні показники виробництва молока. Додаткове доїння корів в обід потребувало додаткових витрат 
праці, заробітної плати та матеріально-технічних i енергетичних ресурсів, що призвело до збільшення собівартості 1 ц молока з 233,05 грн. у першій групі до 236,24 грн. (1,4\%) у другій і 241,18 грн. $(3,5 \%)$ у третій. Незважаючи на це, за рахунок найменшого валового виробництва молока i за умов однакової ціни реалізації $(355,33$ грн/ц), загальна виручка найменшою була у першій групі (519,14 тис. грн), що на 39,05 тис. грн менше, ніж у другій групі $(558,19$ тис. грн) та на 66,83 тис. грн, ніж у третій $(585,97$ тис. грн).

За реалізації молока від дослідних груп за 305 днів лактації найменший прибуток отримали від корів першої групи - 178,65 тис. грн., що на 4,7\% менше, ніж у тварин другої групи та на 5,4\%, ніж корів третьої групи. Проте рівень рентабельності більшим був у першій групі 52,4\%, в другій - дещо менше 50,4\% і в третій $-47,3 \%$.

\section{Висновки}

1. Часткова заміна підвізних (скошених) зелених кормів польового кормовиробництва високоякісним силосом у раціонах дійних корів за стійлового та безприв'язного боксового утримання краще забезпечує їх фізіологічну потребу в сухій речовині 3 одночасним підвищенням концентрації енергії в 1 кг раціону.

2. Комбінована годівля молочних корів влітку, за умови збереження в раціоні стабільного компоненту силосу, дає можливість підтримувати молочну продуктивність на високому рівні.

3. Використання як частково трикратного (перші 100 днів лактації), так і трикратного доїння (за весь період лактації) корів підвищує молочну продуктивність на 7,0 та 11,4\% з одночасним зниженням кормовитрат на одиницю продукції на 7,2 та 11,8\% відповідно.

4. Лактаційна діяльність корів, яких доїли два рази за добу, більш плавна і рівномірна, також інтенсивність молоковіддачі у них була вірогідно більшою, ніж у тварин другої групи на 29,4\% і третьої на $26,5 \%$.

5. Економічна ефективність виробництва молока була вищою у другій і третій групах, де прибуток перевищував показники першої групи на 4,7\% та 5,4\% відповідно.

Перспективи подальших досліджень. Науковопрактичне значення має ефективність використання рецептів збалансованих кормосумішок для годівлі корів за фазами їхньої лактації. В умовах однотипної годівлі корів велике значення мають дослідження можливості введення до складу кормосумішок зеленої маси, не порушуючи їх структуру, замість частини консервованих кормів.

\section{References}

Admin, E.I., \& Korol', A.A. (2006). Besprivjaznoe soderzhanie pri rekonstrukcii molochnih ferm. Tvarynnytstvo Ukrainy, 7, 57-58 (in Russian).

Bomko, V., Kropyvka, Yu., Bomko, L., Chernyuk, S., Kropyvka, S., \& Gutyj, B. (2018). Effect of mixed ligand complexes of Zinc, Manganese, and Cobalt on the Manganese balance in high-yielding cows during first 100-days lactation. Ukrainian Journal of Ecology, 8(1), 420-425. doi: 10.15421/2018_230.

Dundun, V.L. (2016). Development of suckling cattle breeding of Lviv. Scientific Messenger LNUVMBT named after S.Z. Gzhytskyj, 18, 2(69), 48-52. doi: 10.15421/nvlvet6908.

Hnoievyi, V.I. (2003). Kombinovani sylosy yak stalyi korm pry odnotypnii hodivli koriv. Kormy i kormovyrobnytstvo. Mizhvidomchyi tematychnyi naukovyi zbirnyk, 51, 316-318 (in Ukranian).

Hnoievyi, V.I., Ilchenko, O.M., Hnoievyi, I.V., \& Pozniakova, Z.M. (2004). Kombinovani sylosy yak osnova odnotypnykh ratsioniv diinykh koriv. Naukovotekhnichnyi biuleten IT UAAN, 86, 35-38 (in Ukranian).

Kosior, L. (2009). Molochna produktyvnist koriv zalezhno vid sposobiv i kratnosti doinnia. Tvarynnytstvo Ukrainy, 1, 16-19 (in Ukranian).

Ordihovska, O.A., \& Litskyy, V.O. (2016). Loose maintenance and energy efficient production of beef heifers rejected. Scientific Messenger LNUVMBT named after S.Z. Gzhytskyj, 18, 4(72), 47-50. https:/nvlvet.com.ua/index.php/journal/article/view/9 83.

Pidpala, T., \& Yaseniv, S. (2011). Doinnia koriv za umov bezpryviazno-boksovoho utrymannia. Tvarynnytstvo Ukrainy, 1-2, 36-38. http://dspace.mnau.edu.ua/jspui/ handle/123456789/501 (in Ukranian).

Stepanov, A.B., \& Naumov, C.B. (2006). Funkcional'nye svojstva vymeni golshtinizirovannyh korov pri raznyh rezhimah doenija. Perspektivy agropromyshlennogo proizvodstva regionov Rossii $\mathrm{v}$ uslovijah realizacii prioritetnogo nacional'nogo proekta "Razvitie APK". Ufa, 239-242 (in Russian).

Valchuk, O.A., Derkach, S.S., \& Zhuk, Y.V. (2017). Digital center of monitoring of cattle wellbeing. Scientific Messenger LNUVMB, 19(82), 222-225. https://nvlvet.com.ua/index.php/journal/article/view/1 370. 